\title{
Village institutes as a design approach
}

\author{
Nilgün Kuloğlu*

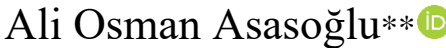

\begin{abstract}
At a glance, architectural space or architectural product is the name given to the artificial shell of actions arising from human needs. These needs range from basic expectations, such as protection, shelter, and production which are necessary for human life, to expectations which require more complex intellectual infrastructure such as culture, belief, and lifestyle. In this study, possible intellectual, architectural approach and design method preferences in Village Institute buildings as architectural products are examined and their contributions to architectural project education are discussed through project work examples. Within the scope of the study, the understanding of education and architecture of the village institutes were examined and possible inferences and concepts which would form the basis of the design were tried to be determined with the help of publications in the literature focused on these subjects. Further, it is aimed to question the relationship of these concepts with those produced in the architectural project studio. The design study subject of the article was carried out in the 2018-2019 Fall Semester at the Department of Architecture at KTU. The first step in the process is turning the inferences and concepts obtained by the executives into a set of information which shall be, eventually, compared with the student project work. This set is retained by the executives for discussion in the article. The second step is the literature research of the students about the project topic and location. Each student reached some concepts from the field and Village Institutes where Trabzon/Beşikdüzü Village Institute was located in the past and advanced his/her design studies through these concepts. Within the scope of this article, the concept sets obtained by the executives and students were compared and discussions were made on overlaps and divergences by associating the aforementioned two steps, and a theoretical framework was formed which was graphically formed.
\end{abstract}

Keywords: context, design education, reading concepts, studio concepts, village institutes.

\section{Introduction}

The choice of the project topic in architectural education is a prerequisite for a creative process that the student and the advisor can internalize together. Therefore, when choosing a project topic according to the semester, the advisor should be as creative as the students in the project design process. For this reason, the choices made depending on the expectations of the semester are very important and it is even meaningful to make choices that are educational not only for the students but also for the advisors. 
In this context, the project topic chosen for the 6th and 7th Semesters at the KTU Architecture Department in the 2018-2019 Fall Semester should be concepts such as "Meaning", "Context", "Place", "Functional Diversity", "Environment" as of the "Program Learning Outcomes" required by the semesters and should also be a topic adequate enough to establish the relations among themselves. In addition, additional concepts or titles such as "Art", "Craft", "Design", "Learning", "Making", "Production", which could relate to the aforementioned concepts, and where the professions they would acquire formed intersections should have been included in the study subjects. All these concepts and titles led the advisors to choose the "Faculty of Fine Arts", which is an educational structure, as the subject, and the former "Trabzon/Beşikdüzü Village Institute" as the place. Thus, while the subject responds to the "Education" subheading in terms of its nature, its physical and semantic boundaries are drawn with its current environment and ruins as the preferred "Place".

The location of the subject is the area where one of the Village Institutes that has a very important place in the education history of our country was located and which is currently used as Anadolu Teacher High School in Trabzon/Beşikdüzü district. It is thought that the fact that a new education structure will be designed on site in one of the Village Institutes, which is one of the basic education stones of our country, will be an important data for the aforementioned student and executive to internalize the subject.

Facts such as "The education-teaching setup in the Village Institutes as an important factor in shaping this project", "the use of space at the time of the institute, depending on this setup including some clues in terms of guiding the designer" and most importantly, "the village institute education-training spirit continuing its traces in the area to be studied" are one of the most important factors in choosing this topic.

While advisors were doing literature research, inferences and conceptual studies on the Village Institutes during the project process, the students were asked to do research on the intellectual structure of the Village Institutes, its establishment purpose, objectives, architecture, understanding of space and the chosen place Beşikdüzü and also, they were expected to reach concepts which would drive the design upon the aforementioned researches.

In this article, rather than conveying a project process or method, it has been aimed to analyze the overlap of the concepts determined about Village Institutes with the concepts in student studies through literature readings.

The method carried out in scope of the article can be explained in two stages. The first stage consists of transforming the theoretical knowledge obtained by the lecturers from the text readings into a conceptual construct, and the second stage consists of evaluating the projects in terms of the concepts generated by the students. This evaluation is not made to measure success in projects. The projects were evaluated in the form of classification of the concepts generated by the students.

From this point, it is aimed to understand the contribution of tools such as the education system, places and setups of Village Institutes to design education. This contribution should be considered in the context of the instruments in question. The unique aspect of the study is that the relationship of village institutes with design education as a tool has not been discussed before.

At this stage, it was necessary to examine the education system of the Village Institutes first and then the spatial configurations of the institutes.

\section{Overview of Village Institutes and Education System}

In this study in which he examined the Village Institutes in the development process, Saka (2010) said, "The phenomenon of village institutes is a social development project that started in rural areas and looks at the development problem wholesale, rather than a simple and plain primary 
education campaign", whereas he summarized the point of view of the institutes on the education of the Republic of Turkey at that time and emphasized the concept of holistic education, (Saka, 2010, p.107).

As it is known, Village Institutes are a bright reflection of the Republic's view of education and were established by Law No. 3803 on April 17, 1940. The efforts of then President İsmet Inönü, Minister of National Education Hasan Ali Yücel and İsmail Hakkı Tonguç, who was appointed as the General Directorate of Primary Education, are very important in the establishment of Village Institutes, (Köy Enstitüleri Kanunu, 1940).

Considered a utopian of education Tonguç (Özsoy, 2008) explains the education principles of the Village Institutes under 7 clauses and expresses his opinions on education as following: "Tomorrow, tens of thousands of young people who will graduate from the Institutes by learning various professions and gaining these weapons will be dispatched to the most desolate villages, travelling to the most remote spots of the country... Through them, these values will be appropriated to the nation, and with the material they will prepare, a new nation will be born, alive and kicking, that we miss..." (Tonguç, 1943, p.147).

The steps taken in education with the Republic are actually the results of an enlightenment. Özdemir summarizes this matter: "The aims and educational expectations of the Turkish Enlightenment, whose roots go back to the middle of the 18th century in Turkey, and which experienced its most productive period with the establishment of the Republic, are basically no different from the goals and expectations of the Western Enlightenment", (Özdemir, 2008, p. 48). Özdemir also defines Turkish Enlightenment with the terms; reason, science, secularism, the importance of the individual, social progress, freedom of thought and press etc. (Özdemir, 2008). These statements somehow summarize the social attitude of Village Institutes.

Ülkü (2008), on the other hand, referring to Özmen, said, "i. H. Tonguç, theorist and founder of Village Institutes was influenced by the opinions of western researchers such as $G$. Kerschensteiner, J. Dewey, H. Pestalozi., F. Frabel, F. Kirby as well as pedagogues such Satı Bey, I. Mahir Efendi, Edhem Nejat and İsmail Hakkı Baltacıŏlu", (Ülkü, 2008), (Özmen, 2004). In this context, it can be said that the educational philosophy of Village Institutes has been shaped by the contributions of valuable thinkers and educators.

It is mentioned in various sources that the American educator John Dewey was invited to Turkey during the establishment of the institutes and was asked to prepare a report. In this report, Dewey pointed out on issues regarding village schools such as "the way of training teachers should be in line with the needs of farmers, which is the basis of village life, and schools should be built quickly in villages" ${ }^{1}$ (Yıldız \& Akandere, 2017).

Baykurt (1997) summarizes the "Principles which make Institutes 'The Institutes"” under 8 topics. These principles are "equality in opportunities and chances", "professional education", "codetermination of students", "devotion and altruism", "continuation of self-learning", "yearround education", "making everyone successful" and "coeducation". He replies the question "How to benefit from Village Institutes education today?" as following; "We have to apply the principles, understanding, methods and teaching techniques of Village Institutes in all our educational institutions from primary school to university... The closure of the institutes after ten years of practice was more than anything a great loss for our democracy, which has been stuck in a

\footnotetext{
${ }^{1}$ Cited from; Yıldız ve Akandere (2017);

John Dewey, Türkiye Maarifi Hakkında Rapor, T.C. Maarif Vekilliği Ana Programa Hazırlıklar, Seri.B, No.1, Devlet Basımevi, İstanbul, 1939, ss.19-22.

Mustafa Şahin, "John Dewey's Influence on Turkish Education System in the Early Republic Era”, European Journal of Education Studies, V.3, I.6, Kosova, pp.622-632.
} 
stalemate for 50 years", (Baykurt, 2021). Apart from the principles mentioned herein, it is possible to come across many principles, understandings and schools that define Village Institutes.

The education approach of Village Institutes adopts the principle of "learning by doing and experiencing". This concept is encountered in most of the studies related to the institutes, (Saka, 2010, p.107), (Batır, 2012).

This model, as known, is the most basic teaching of the Bauhaus School. One of the principles summarized by Walter Gropius in the school that gathers all branches of art under one roof is remarkable within the scope of this research. Gropius states that among these principles, the education system is "participatory" and emphasizes that educators and students "work and produce together", (Erzen, 2009).

Tonguç met the Bauhaus school while he was studying in Germany, and this is one of the important reasons why the education approach in Village Institutes shows such a similarity with the Bauhaus school, (Tonguç 1997), (Ülkü, 2008). In this sense, it would not be wrong to say that Bauhaus which reckons "holistic art" and the Village Institutes based on "co-production" meet on a common ground.

Köksal (2009) sees the Bauhaus as the model that the Republican intellectuals feel closest to among the modernist movements in Europe. She considers Bauhaus "a pedagogical thinking model in which the entire design process can be experienced and observed". And she states that this model offers a healthy modernity to the intellectuals of the Republic, who are trying to establish a new model for themselves, because it brings together creativity and technique, aesthetics and reason, revolutionism and constructivism. (Köksal, 2009).

These similarities in the Bauhaus notions and the educational approach in Village Institutes are not a coincidence. Because both systems of thought aim to reach the most progressive, constructive and educational solutions of their age. Just like in Village Institutes, Bauhaus proposes a "socialist mode of production". Beyazova explains this similarity as following; "It is possible to discover the common points of the Bauhaus model with the Village Institutes and to identify the needs of the new order. Just like in the Bauhaus model, the institutes aimed to harmonize with the modern world with sensitivities such as the unification of art and craft, the elimination of the artist's sacred distinction between the craftsman and the prevention of 'degeneration of products in the transition to industry', which should be emphasized. Another interaction relates to the way of teaching; rote learning has been abandoned, the behavior aiming to learn by doing, encourage instead of obligation, and make the person self-actual has been dominated", (Beyazova, 2012).

In Village Institutes, lessons were given in every field of art, and the lessons were formed from branches of art such as painting, music, theater, folk dances, handworks and handicrafts. Teachers trained in Village Institutes, where art education was highly valued, were asked to adopt the principles of "flexibility and independent education" in their education methods while conveying their art education. (Elpe, 2014).

Another important literature information in terms of education philosophy is Gezer's statement that İsmail Hakkı Tonguç's education philosophy for Village Institutes based on Pestalozzi is relies on 3 principles. These principles are classified as "creation", "production" and "consumption". Under these three concepts, there are detailed explanations that reveal the view of the Village Institutes towards education, (Gezer, 2006, p.86).

Stating that in the years when the institutes were founded, it was not even thought that the "system" theory could be applied to the field of social sciences yet, Başaran (2004) says that the organization of Village Institutes is surprisingly appropriate for this theory. He claims that the five elements (objective, environment, input, process and output) required to comply with the systems theory overlap with the institute setup, (Başaran, 2004). 
The innovative approach of Village Institutes in the field of education may contain much more meanings/concepts/facts than summarized herein. However, within the scope and limits of this study, it has been deemed sufficient to express the intellectual concepts related to the philosophy of education with the terms mentioned here. Of course, there are other concepts that express the Village Institutes and the understanding of education; revolution, enlightenment, democracy etc. However, within the scope of the article, those who can be inputs to the architectural project were preferred. These concepts, which were determined by using the literature during the project work process to be used in the article can be summarized as "participation, learning by doing, learning by living, working together, producing together, holistic art, flexibility, independent education, system, devotion and altruism" (Table 1).

Table 1 Concepts Achieved from Education System Readings: Intellectual Concepts.

participation
learning by doing
learning by living
self learning
working together
producing together
holistic art
flexibility

At this stage of the study, it is important to mention the architecture and space understanding of Village Institutes and to reach some concepts in this context, in order to compare them with the concepts in student projects.

\section{Architecture of Village Institutes}

In addition to its contemporary approach in education, the achievement of architectural projects of Village Institutes through competition shows that the architectural profession, which is not appreciated enough even today, is given the necessary value, and spatial arrangements appear as a product of the same progressive view. Summarizing the project and construction phases, Tonguç said, "The layout and building plans of Village Institutes are obtained through competitions between the architects of the country. According to these projects, roads, buildings, water, electricity and sewerage installations are carried out by the students in the form of course practices and trainings" and also emphasizes the effort of the students in the construction phase, (Tonguç, 1943, p.145).

Makal (2004), on the other hand, underlines the overlap between the education and architecture understanding of the period with the title "meeting on the same principle in the search for architecture and education". He states that as a result of the intersection of the reaction towards the domination of foreign architects and the search for an architecture specific to the conditions of the country (Second National Architecture Movement) and the search for an education suitable for the conditions of the country in the same year, an area where architects could reveal themselves emerged with Village Institutes. Thus, the institutes were also seen as an area where the architects who took part in the Second National Architecture Movement could present their thoughts and approaches, (Makal, 2014, p. 23).

The architectural project competition of Hasanoğlan Village Institute, which is one of the bestknown examples regarding the announcement and conclusion of the competitions was published as following: "... The competition related to the preparation of preliminary projects of the buildings 
to be built for the Village Institute, opened in Hasanoğlan village of the city of Ankara and the detail drawings to be prepared by the architect who will win the first place is ongoing in form of competition being open to all architects of the nation from May 23, 1941 to July 03, 1941...", (Arkitekt, 1941). Later, the winners of the project were announced to the public with the announcement: "The Hasanoğlan Village Institute project competition was concluded, the first place among the participating projects was the joint project of Master Architect Associate Professor Kemal Ahmet, Associate Professor Orhan Safa and Adnan KuruyazıcI, and the second place was won by Professor Sedat Hakkı's project", (Arkitekt, 1941).

It is stated in various sources that, in general, the common basic units of each institute consist of: "dormitories, mess halls-kitchens, laundries-bathrooms, open-air wash taps, field toilets, infirmary, ovens, cooperatives, barns, corrals, studs, poultry houses, apiaries, fish houses, water tanks and pools, various warehouses, power plant, vineyards, fields, nurseries, groves, flower beds, various agricultural areas, administration rooms, teacher's houses, classrooms, libraries, laboratories, ateliers, music, theater and meeting halls, sports fields, practice areas, playgrounds" and similar spaces. (Türkoğlu, 2000, p. 202), (Çetin \& Kıran, 2019).

It is known that one of the important concepts put forward in the architectural program of Village Institutes prepared by Tonguç is the concept of "cluster". A structure with training, accommodation and service spaces is envisaged for each cluster, (Çorakbaş, 2014).

According to Kirby (2019), "cluster" is basically an administrative unit and is seen as a phenomenon that affects the structuring of the institute. In some institutes, cluster units formed the architectural basis of the institute. Kirby says that the institute's making these buildings is a good mix of architectural science and pragmatic village architecture. (Kirby, 2019).

According to Baysal (2012), clusters are defined as "dividing a large population into work and education programs in groups" and while it combines daily life and education, it is foreseen that many small-scale buildings with the same function are planned instead of large and single buildings", (Baysal, 2012, p. 143).

The understanding of education in Village Institutes is based on the experience of establishing the space together. In an article describing the educational life of graduates from the institutes, Karakuş emphasizes the students' experience of establishing a space and also includes Ömer Faruk Diril's statement in this respect: "... We tied the trusses together in such a way that those who saw were astonished. We had completed the roof and laid the tiles by restraining it completely on opposite walls without placing any poles.... We had reached the goal. All students started to eat our meals together, and on weekends we held our meetings and conferences in our cafeteria..." building construction also means the construction of life. Karakuş summarizes this situation as follows; "Village Institutes also set an example for the social production of space, new structures that are shaped entirely by their own needs, designed by Hungarian master builders, built by students and transforming the practices in their daily lives, are spaces where they feel belonging to", (Karakuş, 2017). The concept of "belonging" mentioned herein draws attention as one of the most basic and vital concepts in the field of architecture.

Şimşek and Mercanlıoğlu, point out that Village Institutes, which also have a progressive understanding in the context of planning, are the product of a planned approach, and present an evaluation of 21 items in which these indicators are listed. (Şimşek \& Mercanlıoğlu, 2018). In the study where the general principles related to the location were summarized as "Far from cities but close railways and other main transport routes and located in villages with large public domain convenient for reclamation", it is observed that some of these indicators step forward. Among them, those that concern the field of architecture can be quoted as; "campus model", "the fact that they shall not only be an education space but also living spaces", "being interaction environments covering all workers", "priority of culture and art activities", "collective production" and "being indigenous". 
To give an example on the subject of site selection, Kocabaş cites the qualifications of Ortaklar that were influential in his selection for the institute, from the official letter of Hamdi Akman dated 1943 to İsmail Hakkı Tonguç: "The facts that the land, which is $3 \mathrm{~km}$ away from Ortaklar village, is close to the Söke railway, that the Naipli Stream flows in the middle of the land, that there is a hot spring on its edge, that the ruins of the ancient city of Mağnus (Magnesia) are located near the land, that it is suitable for all kinds of agriculture and the private parts of the land can be easily expropriated, stands out among options." Considering the current location of the land, Kocabas says that these qualities continue, and the fact that it is $21 \mathrm{~km}$ away from the Ancient City of Ephesus and Selçuk reinforces the importance of its location, (Kocabaş, 2014, p. 225).

Saying that "the activity of a community on a certain section of the space creates the space", Lefebvre (2014, 67-68) almost talks about Village Institutes in the context of space-human duality. Confirming this, Karakuş (2017) states in a study they conducted with graduates of the institute that they perceive their school place as "a new home", "establishment of a common identity". Further, he explains that the students are aware of the fact that they start to change both the physical environment and life with their studies and that they remember this with all their vitality today, with the relationship of "space and memory". He considers the concept of cluster which is mentioned I many sources the "establishment of a common identity", (Karakuş, 2017).

It is possible to reach other sources, detailed drawings and photographs on the architecture of the Village Institutes. Within the scope of this article, it is thought that the concepts produced about the institute spaces are sufficient. These concepts can be summarized as "campus, cluster, living spaces, home, place, space and memory, interaction environment, culture and art, being indigenous, common identity".

Table 2 Concepts from Architectural Space Readings: Spatial Concepts.

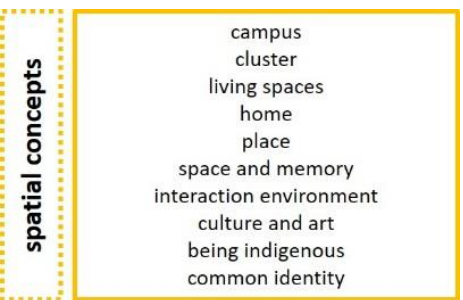

If the intellectual and spatial readings that make up Table 1 and Table 2 are summarized in a conceptual setup within the scope of this article, it is thought that they can be arranged as shown in Table 3.

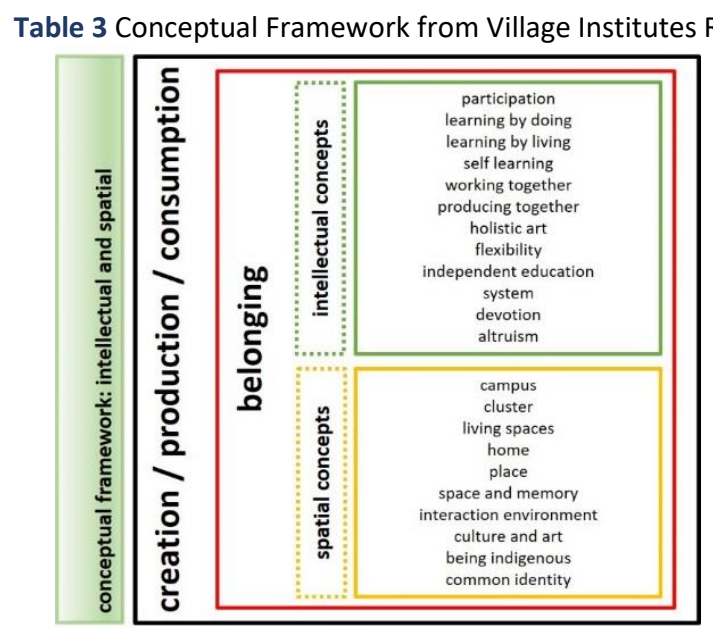

At this stage of the article, it was deemed necessary to give some spatial and historical information about the Trabzon-Beşikdüzü Village Institute which is the subject of the semester project. 


\section{Trabzon-Beşikdüzü Village Institute: Past and Present}

The opening years of 21 Village Institutes are between 1937 and 1948. According to this information, Beşikdüzü Village Institute was established in 1940 in the Vakfikebir district of the province of Trabzon, (Akar, 2011, p. 21).

Gazalcı states the establishment date of the institute as July 08, 1940. The Beşikdüzü Village Institute has 645 graduates. It is known that Tonguç said to Arman, the director of the institute, "Your field is the Black Sea, you will use it" because the institute did not have enough land when it started education, (Gazalcı, 2021).

In his article, Makal mentions that the winner of the Beşikdüzü Village Institute competition is stated as Master Architect Ahsen Yapanar, (Makal, 2014, p. 23). However, in the article of Çorakbaş and Atalay describing the institute, Asım Mutlu is also mentioned as an architect in addition to Yapanar. It is also stated in the same article that none of the buildings constructed upon the architectural project competition of the Beşikdüzü Village Institute have survived, (Çorakbaş \& Atalay, 2017).

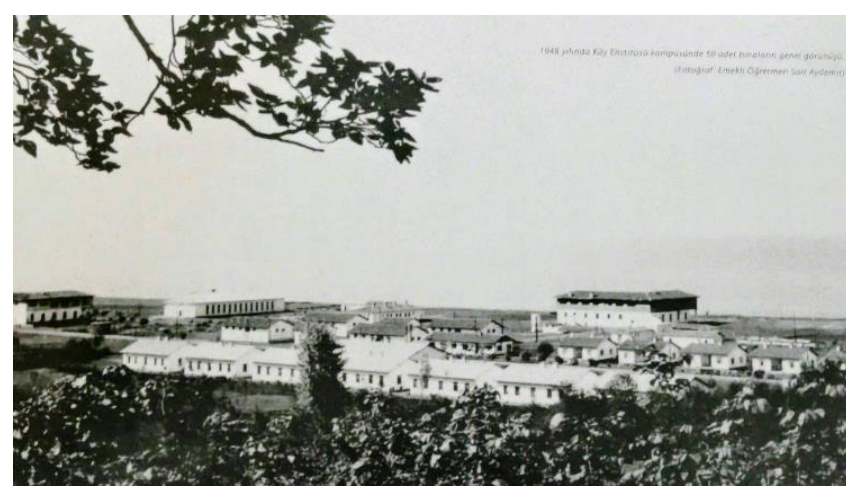

Photo 1 View of the Beşikdüzü Village Institute Campus in 1948, (URL 1).

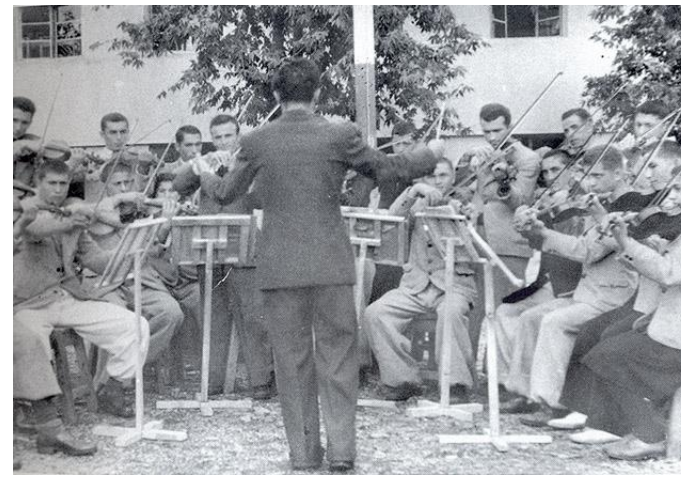

Photo 2 Children Learning to Play Violin at the Beşikdüzü Village Institute, (URL 1).

Regarding the Beşikdüzü Village Institute, its architecture and spatial transformation in different periods, Çorakbaş and Atalay's article titled "Beşikdüzü Village Institute: Destruction of Spatial Memory" can be examined in detail. This process can be briefly summarize as following;

- The campus had a total of 4 periods and the constructions were built in the lower periods of the 1st period (1A, 1B and 1C), (Figure 1),

- The architectural project competition was announced in 1940,

- The first building was constructed according to the project in 1942,

- It settled in its own area borders in 1948,

- The buildings were used for purposes other than their functions in different periods,

- The institute campus was registered in 1999,

- With the recent demolitions, the last remaining structures from different periods of the institute were also demolished, (Çorakbaş \& Atalay, 2017). 


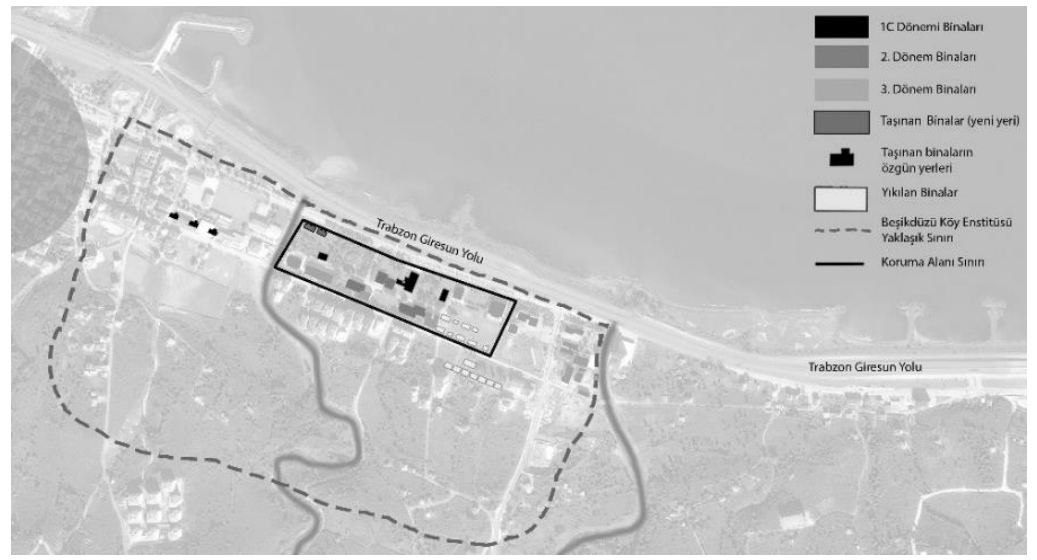

Page | 258

Figure 1 Map showing the Beşikdüzü Village Institute Buildings and Periods, (Çorakbaş \& Atalay, 2017).

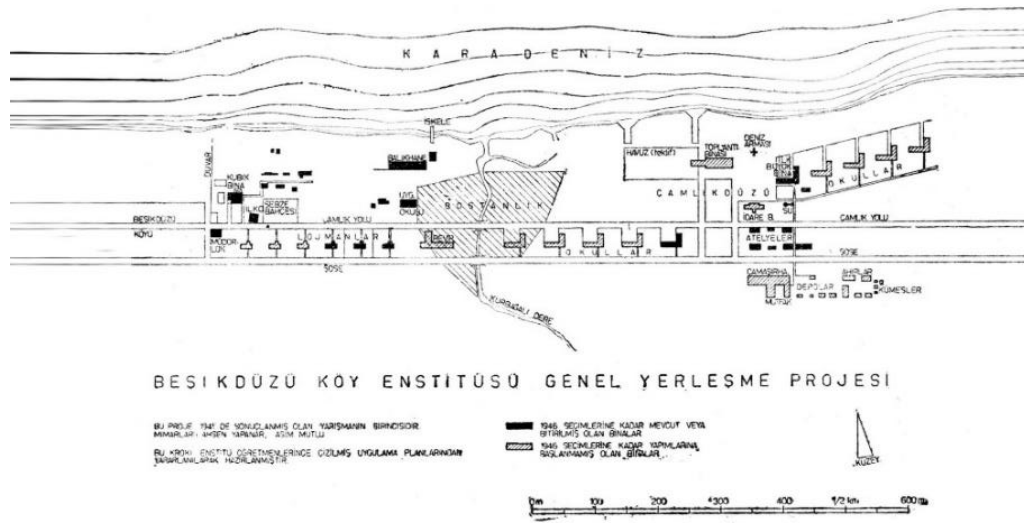

Figure 2 The Beşikdüzü Village Institute General Layout Project, (Çorakbaş \& Atalay, 2017)

It is observed that the teacher lodgings, which are among the important buildings in the Village Institute, were built in the "serander" building typology specific to Trabzon and all of these buildings have been demolished today. It is also understood that later on, these structures were rebuilt with a different function in 2014 by the decision of the Trabzon Regional Conservation Board in 2000, but they did not adhere to their original form and could not convey the architectural value of the original structures. Çorakbaş and Atalay make suggestions for the future by saying that the spatial memory that carries the "spirit of the place" has disappeared, and they offer their ideas by saying that some projects can be developed to compensate for this loss, (Çorakbaş \& Atalay, 2017).

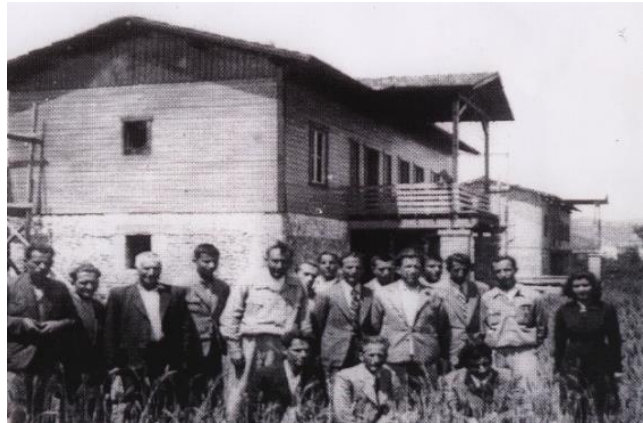

Photo 3 A View of the Beşikdüzü Village Institute Lodgings, (Çorakbaş \& Atalay, 2017).

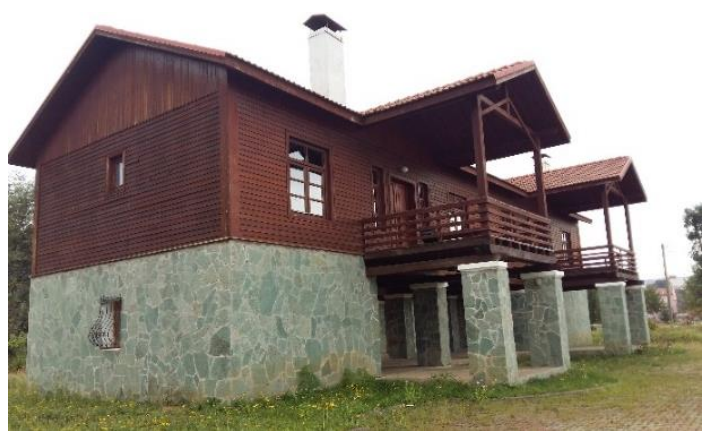

Photo 4 The reconstruction of the Beşikdüzü Village Institute Lodgings in 2014, (From Beyza Atalay's Archieve, 2016).

The Beşikdüzü Village Institute continues to serve as the Beşikdüzü Anatolian Teacher High School since the 1989-1990 academic year. The institution, which provides education with mostly new buildings, also has a place where the years of the institute are exhibited under the name of "The Village Institute with Photographs". 
After this brief introduction, the main idea of the project process and the article, which is carried out on the concepts obtained from the readings and the concepts produced by the students, is conveyed.

\section{Studio Process and Conceptual Relations}

It was previously stated in the 2018-2019 Fall Semester KTU Architecture Department 6th and 7th Semester that the Beşikdüzü Village Institute was chosen as the place in the project process and the Faculty of Fine Arts was chosen as the subject. ${ }^{2}$ What is expected from the 6th and 7 th Semester project in the Department of Architecture at KTU can be summarized as the acquisition of competence by students in the evaluation of the urban context, and the transfer of social and functional traces to architecture. The process can be carried out by group teachers in different ways. However, the common goal is to gain this competence to architect candidates. ${ }^{3}$

Within the scope of the article, it is not aimed to describe a project method or process. Because there are many studies produced on this subject. Within the scope of this article, the role of subject selection in guiding the designer and the importance of the "village institute" phenomenon in guiding the design was aimed to emphasize. For this reason, the institutes were read from different perspectives by the advisors, and it was questioned whether the concepts obtained were related to the concepts in the student projects. From this point of view, it can be concluded that the stronger this relationship, the more accurate the choice of subject.

In this section, student projects are introduced in terms of their conceptual approaches. What is meant to be understood is the relationship between the concepts produced by the students during the research phase and the concepts determined by the advisors through the readings, depending on the "village institute" phenomenon. The map of the study area is shown in figure 3.

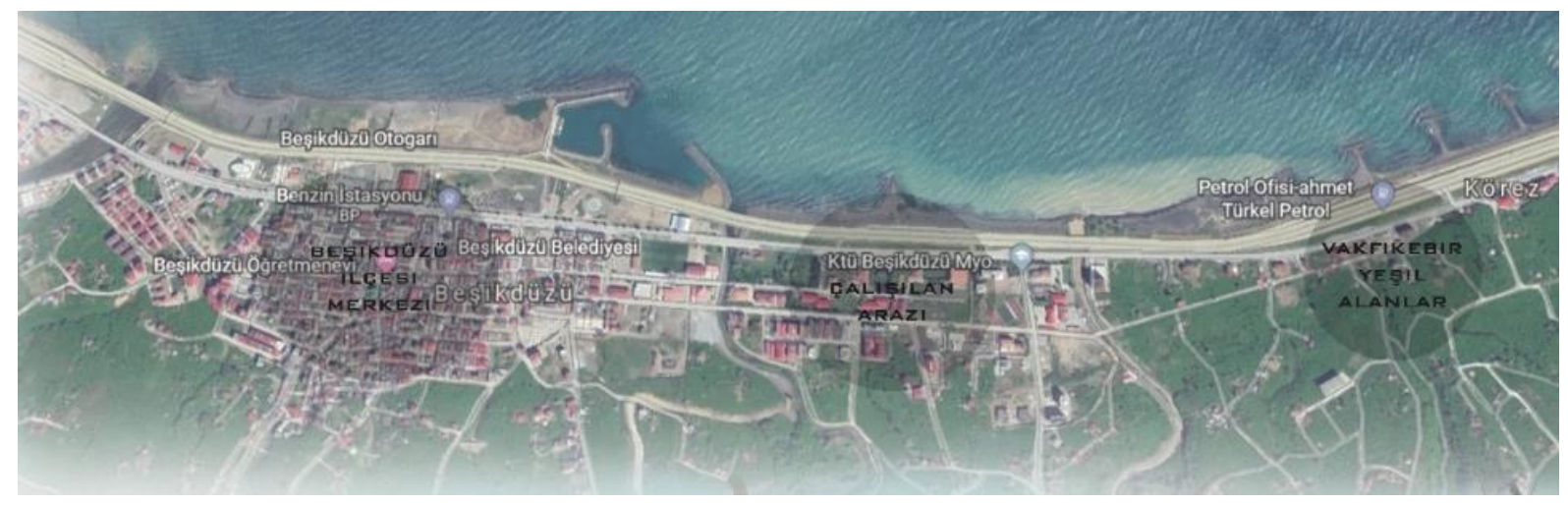

Figure 3 Study Area and Its Surroundings on Google Earth Image Prepared by the student: Fatma Zehra Yüter

Projects selected to determine the relationship between concept clusters and brief explanations are shown in Table 4-10.

\footnotetext{
${ }^{2}$ In this semester project, the subject of "Faculty of Fine Arts" was studied by a part of the class. Within the scope of the article, examples from the work of 2 groups are given. The projects exemplified herein were selected among the groups of Prof. Dr. Ali Asasoğlu \& Research Assistant Barış ilban and Prof. Dr. Nilgun Kuloglu \& Dr. Student Oğuz Kırcı who are also the authors of the article. ${ }^{3}$ For information, please refer to: KTU Faculty of Architecture, Department of Architecture Educational Outputs. http://www.katalog.ktu.edu.tr/DersBilgiPaketi/generalinfo.aspx?pid=263\&lang=1
} 
Table 4 Hüda Koçal, Faculty of Fine Arts Design. Concept/Concepts: Unity/Bond/Bonding
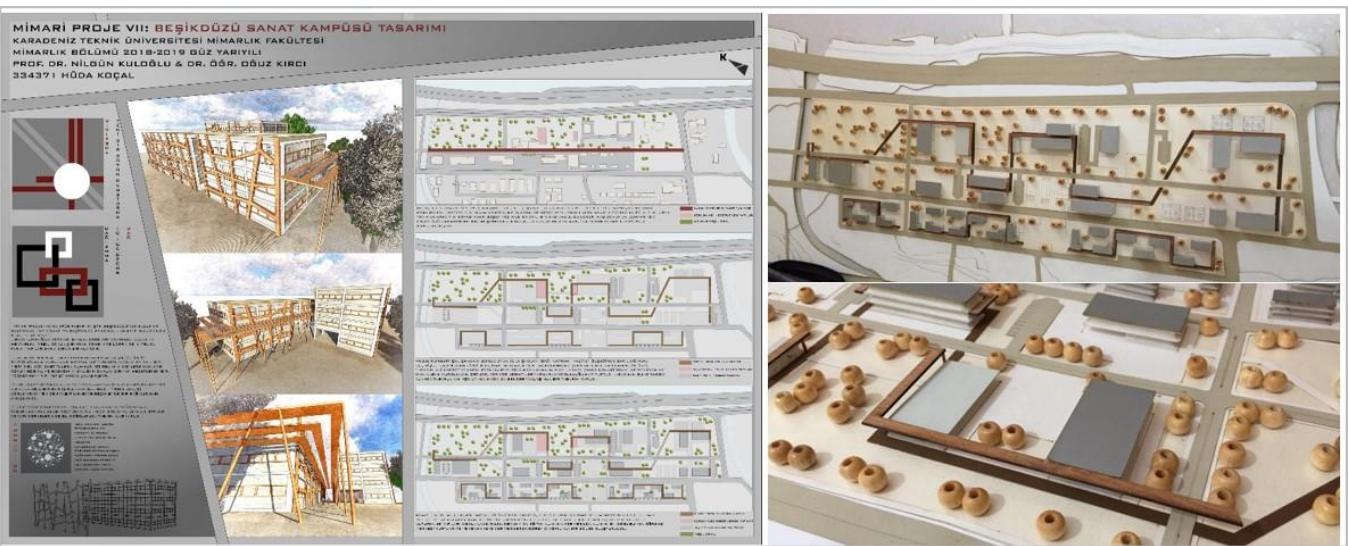

Page | 260

The reflection of the selected concepts in the study to the space is aimed to determine the relations between the masses to be provided with the semi-open cover element that covers the entire space.

Table 5 Elif Barbaros, Faculty of Fine Arts Design. Concept/Concepts: Trace/Belonging/Unity/Solidarity
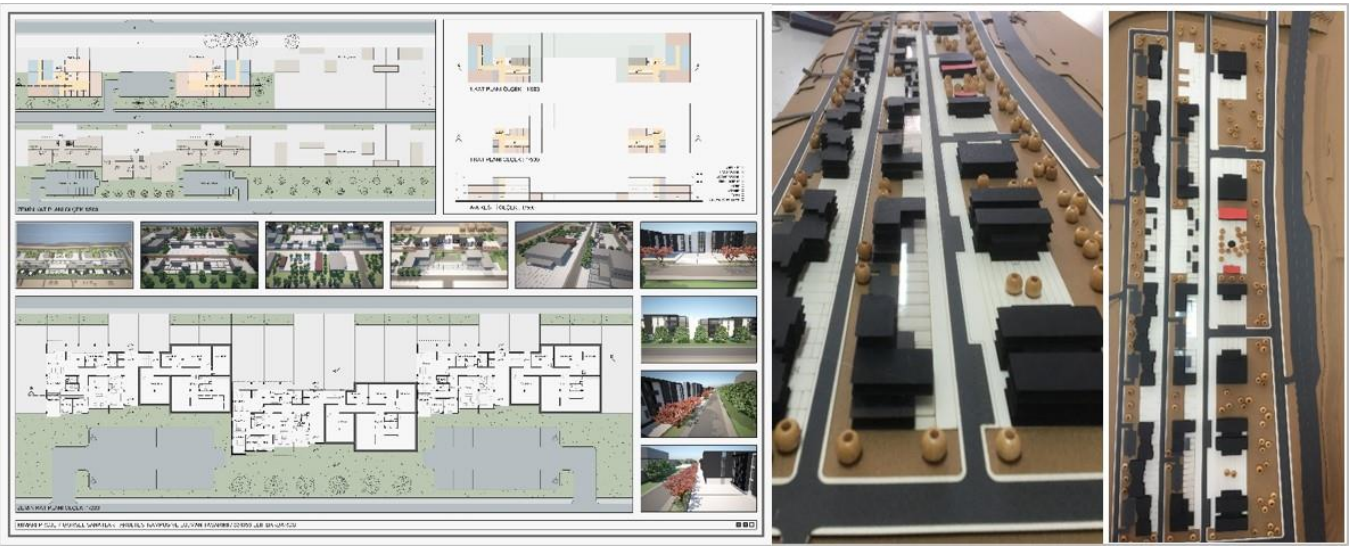

The reflection of the concepts chosen in this project on the space is seen in the settlement decisions and the distribution of the space types within the land.

Table 6 Fatma Menteşe, Faculty of Fine Arts Design. Concept/Concepts: Memory Spaces/Spirit of Place (Genius Loci)

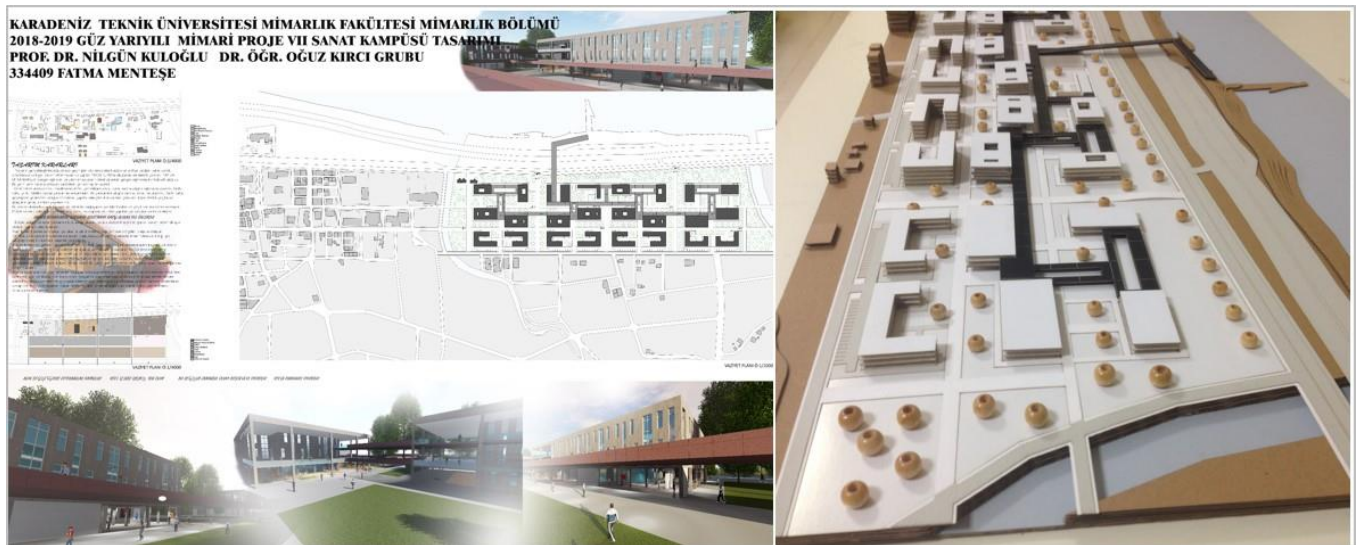

In the project, the reflection of the concepts to the space was sought in the memory of the place. The elements and spatial formations that the place reminds us are tried to be followed. 
Table 7 Ramazan Özbek, Faculty of Fine Arts Design. Concept/Concepts: Association/Communication

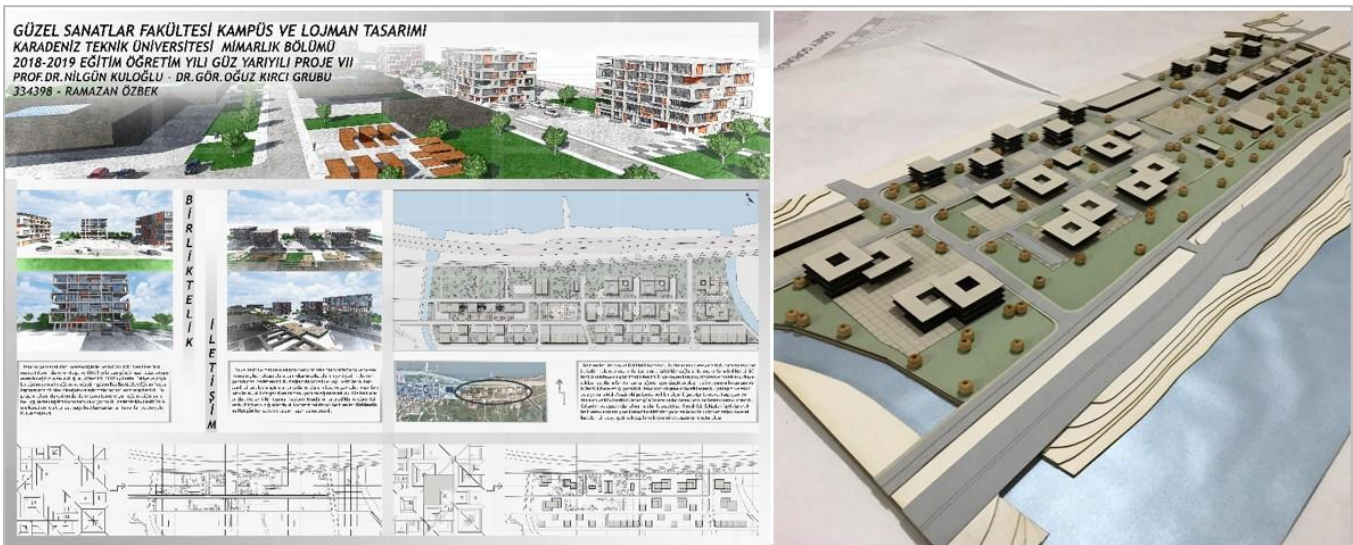

In this study, it is aimed to ensure the reflection of the concepts to the space, mass relations and the location selection of the masses on the area.

Table 8 Elif Baykal, Faculty of Fine Arts Design. Concept/Concepts: Involving/Comprehending/Context
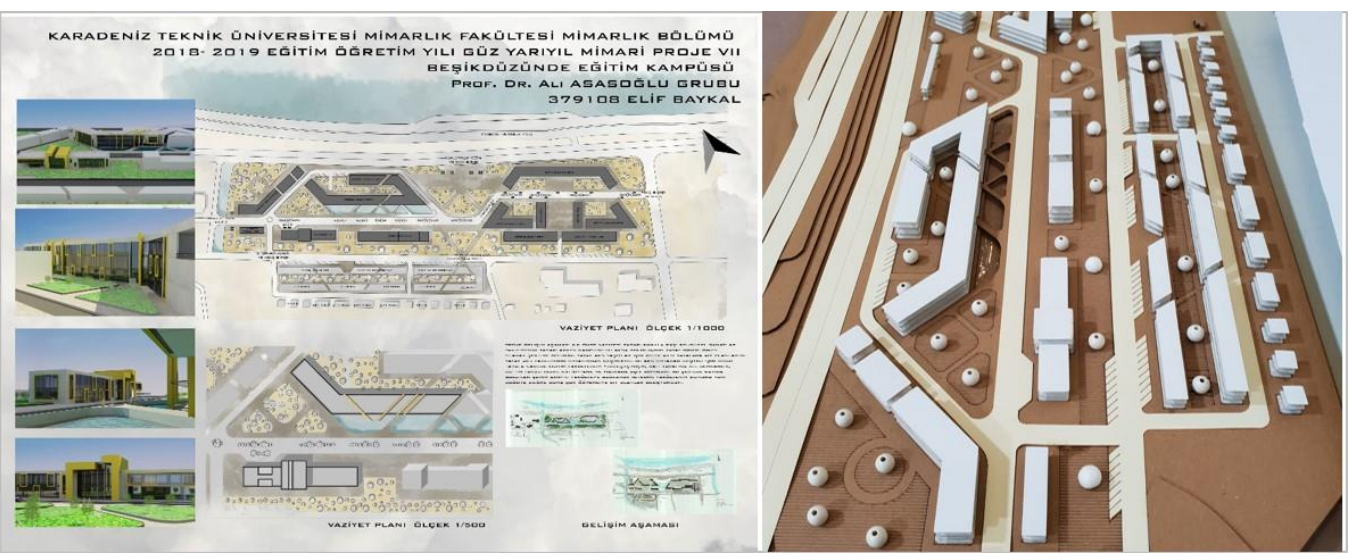

The contextual relationship established with the city is aimed to be in an inclusive and inclusive order. Context was seen as a phenomenon that should be conveyed to the future.

Table 9 Elif Zümrüt, Faculty of Fine Arts Design. Concept/Concepts: Union of the Contrasts/Emphasis
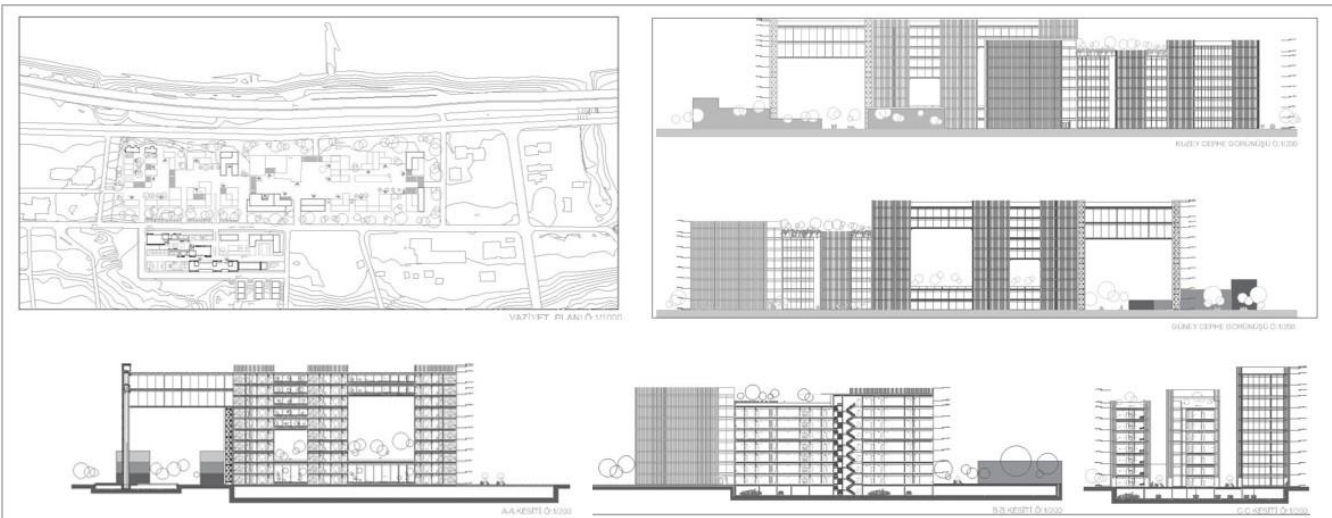

The project achieves its relationship with the context by making use of the third-dimension opposition. It was requested that the relationship with the context shall be terminated with emphasis and conceptual implications were evaluated in this sense. 
Table 10 Yasemin Çilek, Faculty of Fine Arts Design. Concept/Concepts: Focus/Context/Junction

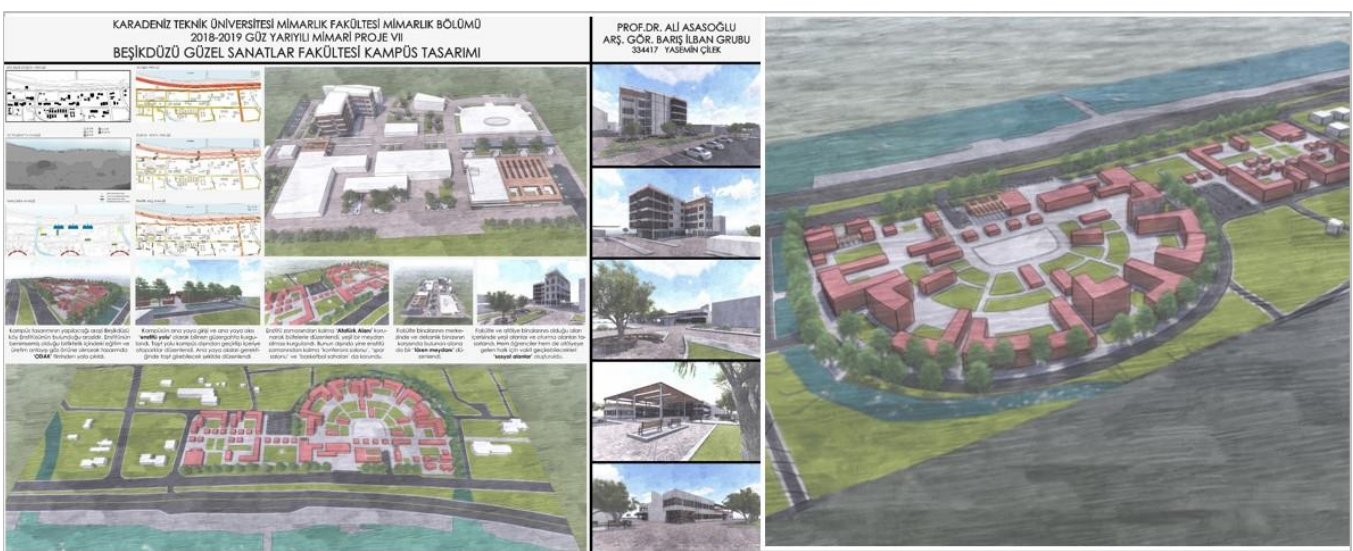

The project attempted to add context through the creation of physical focus. The physical focus is assumed to be an end.

\section{Findings And Discussions}

The concepts that can be the starting point for the projects in line with the information obtained by the students from the research phase are classified as shown in Table 11. These can be summarized as; "unification, bond, attachment, trace, belonging, unity, togetherness, places of memory, genius loci, togetherness, communication, inclusion, comprehension, context, unity of opposites, emphasis, focus and attachment".

Table 11 Concepts Created by the Students in Scope of the Project

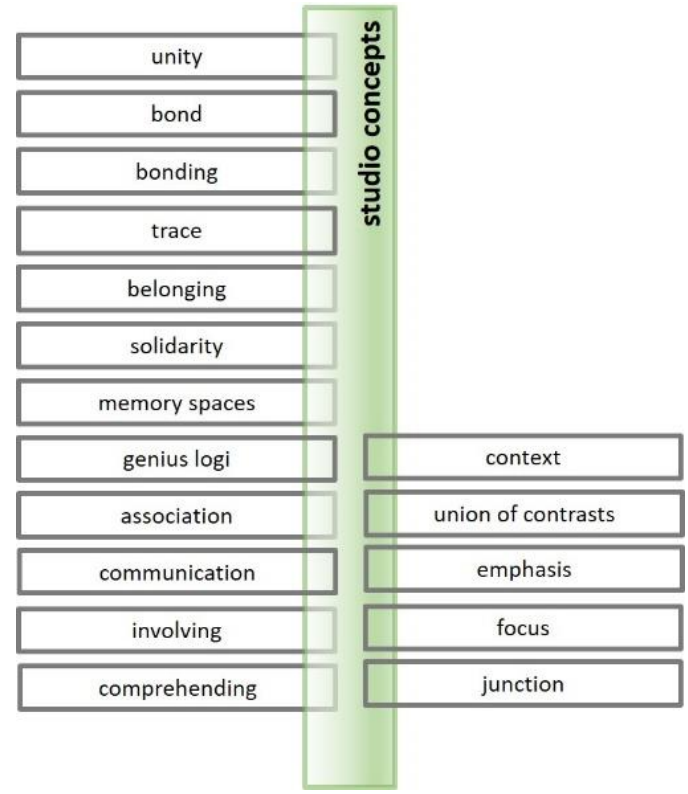

The relationships between the concepts "obtained from the literature readings" and "produced within the scope of the studio" can be summarized as a whole as shown in Table 12. The table shows the relationship between the concepts obtained from the readings and the studio concepts symbolically; 
Table 12 The Relation of Intellectual and Spatial Concepts Obtained from Readings with Studio Concepts

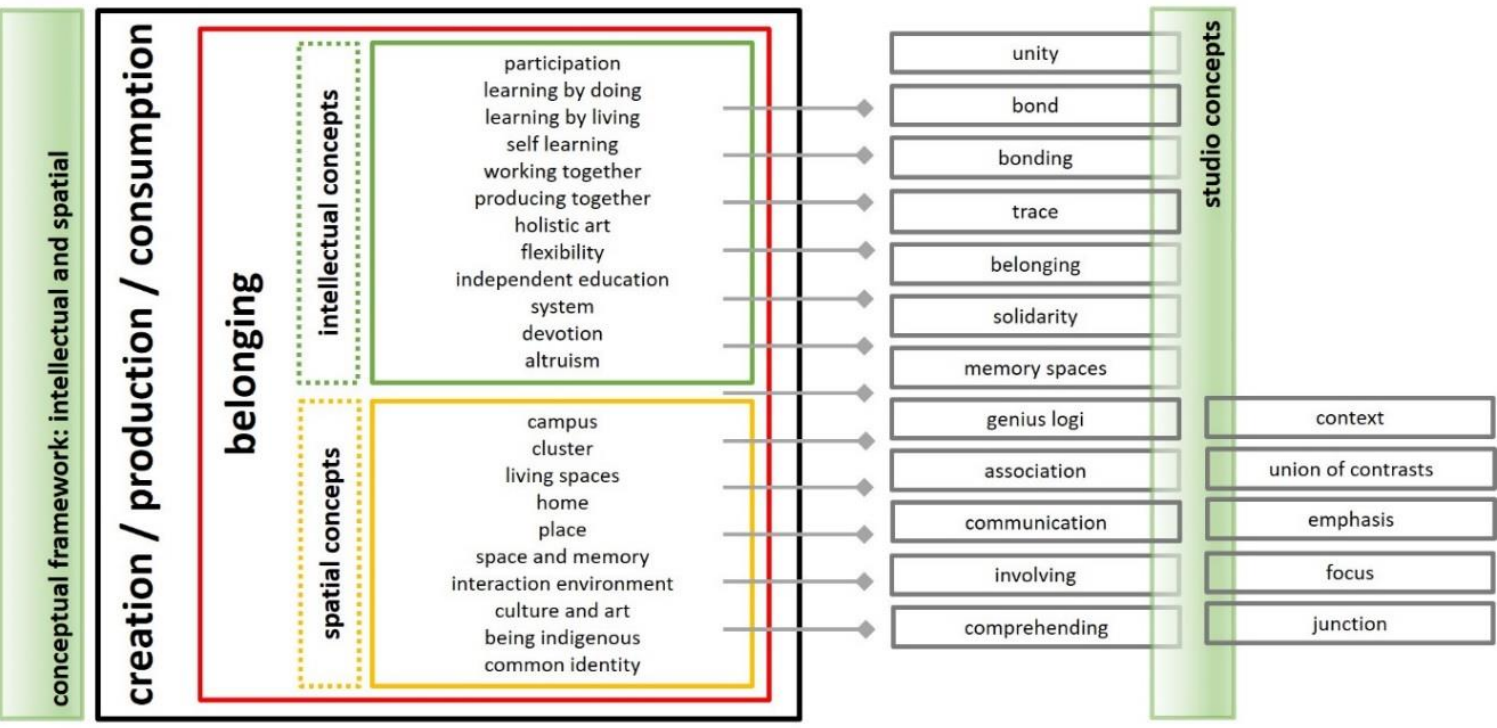

By looking at the analysis table, it can be said that there are significant relationships between the concepts obtained from the readings and the others, although there is no one-to-one correspondence.

- The concept of "participation" derived from the readings; "unity", "togetherness", "solidarity", "communication"

- The concepts of "learning by doing, learning by living and self-learning"; "spirit of the place" and "communication"

- The concepts of "working together and producing together"; "connection", "unity", "togetherness", "solidarity" and "communication"

- The concept of "holistic art"; "unity", "solidarity"

- The concept of "system"; "emphasis" and "focus"

- The concepts of "devotion" and "altruism"

- The concept of "campus" "belonging", "involving" and "comprehending"

- The concept of "cluster"; "unity", "belonging" and "bonding"

- The concept of "living spaces"; "memory spaces"

- The concepts of "home and place; "bond", "unity", "belonging" and "junction"

- The concept of "space and memory"; "trace", "memory spaces" and "spirit of place"

- The concept of "interaction environment"; "unity", "togetherness", "solidarity" and "communication"

- The concept of "being indigenous"; "belonging" and "context"

- The concept of "common identity"; "belonging", "togetherness" "spirit of place" and "solidarity", significantly overlap with the project concepts.

A reading concept may overlap with one or more project concepts. Or reading concepts may not have equivalents in project concepts. However, it is seen that; it is noteworthy that the concepts obtained from the readings overlap with the project concepts.

From another point of view, project achievements can also be evaluated through the context phenomenon. Venturi (2019) inference from the designer's point of view; is defined as; "the existing conditions surrounding a building site become part of the design problem". "Current conditions" may not always refer to the time period being lived in. In this project process, the issue of "current conditions" can be considered as "intellectual and physical traces from the past". In this sense, the projects produced based on the phenomenon of "village institutes" have been solved as a contextual problem that perhaps does not even have physical traces. "Context", one of the most 
important tools of architectural design, becomes a phenomenon that is reflected in the project process by itself.

In conclusion; In the light of these overlaps, regardless of the method of the project studio, it can be concluded that the students' readings and inferences about Village Institutes give them very important clues to start the project. It can be said that this kind of creative subject and location selection has a great contribution to the internalization of the process not only for the students but also for the faculty members and assistants running the studio. It is possible to say that the concepts obtained as a result of the readings overlap significantly with the concepts produced by the students, indicating the consistency in the selection of the subject and place and a creative process. Projects produced with these steps will also give the most appropriate response to the "context" phenomenon.

\section{References}

Akar, H., (2011). Türkiye'deki köy enstitülerinin toplumsal değişmedeki yeri, Yüksek Lisans Tezi, Dokuz Eylül Üniversitesi, Eğitim Bilimleri Enstitüsü, Eğitim Bilimleri Ana Bilim Dalı, Eğitim Programları ve Öğretim Programı, İzmir.

Arkitekt Cilt: 1941 Sayı: 1941/42-01-02 (121-122), 46-48, 3803 Sayılı Kanuna Tavfikan Ankara Hasanoğlan Köyü'nde Açılan Enstitünün Avam Projelerine Ait Müsabaka Şartnamesi, (1941).

Retrived from: http://dergi.mo.org.tr/dergiler/2/106/1179.pdf

Arkitekt, Haberler, Cilt: 1941, Sayı: 1941/42-03-04 (123-124), 98.

Retrived from: http://dergi.mo.org.tr/detail.php?id=2\&sayi_id=107

Başaran, I. E., (2004). Sistem kuramı ve köy enstitüsü, Yeniden İmece, Yıl 1, Sayı 2, Şubat, İzmir, 64-69.

Batır, B., (2012). Akpınar örneğinde bir aydınlanma projesi olarak köy enstitüleri, Samsun Sempozyumu, 1316 Ekim, Editörler: Prof. Dr. Mahmut Aydın, Doç. Dr. Bekir Şş̧̧man, Yrd. Doç. Dr. Selahattin Özyurt, Yrd. Doç. Dr. Hasan Atsız, CiLT III, Samsun Valiliği, Samsun, 524-536.

Baykurt, F., (2021). Unutulmaz köy enstitüleri, Literatür Yayınları, 7. Basım, İstanbul.

Baysal, E., (2012). Köy enstitülerinde mekân kurgusu ve mimari yapılanma, Düşünen Tohum Konuşan Toprak, Cumhuriyetin Köy Enstitüleri, 1940-1954, Suna ve İnan Kıraç Vakfı istanbul Araştırmaları Enstitüsü, İstanbul, 136-158.

Beyazova, P., (2012). Bauhaus geleneğine bakış, Sosyoloji Notları 9, Ocak-Şubat-Mart, Ankara, 33-38.

Çetin, S. \& Kıran, G., (2019). Ortaklar köy enstitüsünde modern mimarlı̆ı̆n izleri, Journal of Arts, Cilt/Volume 2, Sayı/Issue 3, 169-180.

Çorakbaş, F., (2014). Mimari koruma perspektifinden ortaklar köy enstitüsü yerleşkesi ve Mualla Eyüboğlu, Ortaklar köy enstitüsü 70 yaşında, Birinci Basım, Yayına Hazırlayan: Prof. Dr. Kemal Kemal Kocabaş, ìzmir, 105-116.

Çorakbaş, F., K. \& Atalay, B., (2017). Beşikdüzü köy enstitüsü: mekansal hafızanın yıkımı, Tanıklıklarla Beşikdüzü Aydınlığı, Yayına Hazırlayan: Prof. Dr. Kemal Kemal Kocabaş, Yeni Kuşak Köy Enstitüler Derneği Yayınları, İzmir, 113-128.

Elpe, E., (2014). Köy Enstitüleri ve Sanat Eğitimi, Batman Üniversitesi Yaşam Bilimleri Dergisi; Cilt 4, Sayı 2.

Erzen J., (2009). Bauhaus'un 90. yllında, Mimarlık 349. Retrived from:

http://www.mimarlikdergisi.com/index.cfm?sayfa=mimarlik\&DergiSayi=363\&ReclD=2185\#

Gazalcı, M., (2021). 21 Köy enstitüsü-çınarlar anlatıyor, Bilgi Yayınevi, Ankara.

Gezer, N., (2006). Köy enstitülerinde oluşmuş düşün kaynağııın bugüne ulaşabilmesinin nedenleri ve sınanan gerçekleri, Yeniden İmece, Ağustos, 85-86.

Karakuş, M., (2017). Toplumsal bellek bağlamında mezunların anlatımıyla köy enstitüleri deneyimi, Uludağ Üniversitesi Fen-Edebiyat Fakültesi Sosyal Bilimler Dergisi, C. 18, S. 33, s. 719-741.

Kirby, F., (2019). Türkiye'de köy enstitüleri, Niyazi Berkes, (Çev.), 8. Baskı, İstanbul.

Köksal, D., (2009). Cumhuriyet ideolojisi ve estetik modernizm: baltacıoğlu, yeni zamanlar ve bauhaus, Bauhaus: Modernleşmenin Tasarımı/Türkiye'de Mimarlık, Sanat, Tasarım Eğitimi ve Bauhaus, A. Artun \& E. Aliçavuşoğlu (Eds), iletişim Yayınları, ìstanbul, 241-261.

Köy Enstitüleri Kanunu. (1940) 22 Nisan 1940 tarihli ve 4491 sayılı Resmi Gazete.

Kocabaş, K., (2014). Aydınlanma yazıları, Yeni Kuşak Köy Enstitülüler Derneği, İzmir.

Makal, O., (2004). Şimdi Korunması Gereken Kültür Varlıkları, Yeniden İmece, Şubat, 21-28.

Özdemir, O., (2008). Köy enstitüleri ve yeni ortaçağın eğitim sorunu, Mersin Üniversitesi Eğitim Fakültesi Dergisi, Cilt 4, Sayı 1, 46-54. 
Özmen, M., (2004). Türk aydınlanmacılığı ve köy enstitüleri, Müdafaa-i Hukuk Dergisi, 69, 46.

Özsoy, S., (2008). Bir eğitim ütopyacısı: İsmail Hakkı Tonguç, Toplum ve Demokrasi, 2 (3), Mayıs-Ağustos, 267276.

Saka, N. (2010). Köy enstitülerinin Türkiye’nin kalkınma sürecindeki yeri, (Yüksek Lisans Tezi), İstanbul.

Şimşek, G., \& Mercanoğlu, C., (2018). Bir "planlama örneği” olarak köy enstitüleri deneyimi, Planlama 28(3), 261-281.

Page| 265 Tonguç, İ. H., (1943). Köy enstitülerimizde eğitim ve öğretim ilkeleri, Ankara Üniversitesi, Dil ve Tarih Coğrafya Fakültesi Dergisi, Cilt 1, Sayı 5, 137-147.

Türkoğlu, P., (2000). Tonguç ve enstitüleri, Türkiye İş Bankası Kültür Yayınları, İstanbul.

Ülkü, C., (2008). Sanat eğitimi, sanat ve köy enstitüleri, Mersin Üniversitesi Eğitim Fakültesi Dergisi, Cilt 4, Sayı 1, 37-45.

Yıldız, N. \& Akandere, O., (2017). Köy enstitülerinin ideolojik yapısı, Çağdaş Türkiye Tarihi Araştırmaları Dergisi, Journal Of Modern Turkish History Studies, XVII/35 (Güz/Autumn), 275-316.

URL 1. https://www.ayamfolklor.com/aydinlanmanin-besigi-besikduzu-koy-enstitusu/

Venturi, R., (2019), Mimari kompozisyonda bağlam, Ülkü Özten (Ed)., Mimari bağlamsalcılık II, Eskişsehir Osmangazi Üniversitesi Yayınları, No:329, Eskişehir.

\section{Resume}

Nilgün Kuloğlu was born in 1963, in Ankara, Turkey. She graduated from Karadeniz Technical University, Department of Architecture, in 1984. In 1987, she completed her master degree. In 1984-1986, she has worked an architectural office in Trabzon. She completed PhD. thesis in 1994 at the same University. She worked in order to prepare conference, exhibition and competition at Karadeniz Technical University, Department of Architecture on different years and completed a European Commission-Leonardo Da Vinci Project in 2009 with her colleagues. The project's name is: "Designtrain: Training Tools for Developing Design Education", and project's web site is: www.designtrain-Idv.com. She still works as Prof. Dr. at Karadeniz Technical University, Faculty of Architecture-Department of Architecture and continues professional activities at the same university.

Ali Osman Asasoğlu was born in 1960, in Ankara, Turkey. He graduated from Karadeniz Technical University, Department of Architecture, in 1985. In 1988, he completed her master degree. He completed PhD. thesis in 1994 at Karadeniz Technical University, Department of Architecture. He worked in order to prepare conference, exhibition and competition at Karadeniz Technical University, Department of Architecture on different years and completed a European Commission-Leonardo Da Vinci Project in 2009 with her colleagues. The project's name is: "Designtrain: Training Tools for Developing Design Education", and project's web site is: www.designtrain-Idv.com. In 2005, he served as the vice dean of the KTU Faculty of Architecture. Between 2012 and 2013, he served as Deputy Dean of the Faculty of Architecture at Muğla Sıtkı Koçman University. He still works as Prof. Dr. at Karadeniz Technical University, Faculty of Architecture-Department of Architecture and continues professional activities at the same university. 